\title{
On the synonymy of Tetragnatha qiuae (Aranei: Tetragnathidae)
}

\section{О синонимии Tetragnatha qiuae (Aranei: Tetragnathidae)}

\author{
Yuri M. Marusik ${ }^{1,2}$, Kirill G. Mikhailov ${ }^{3}$, Evgeny A. Kuzmin ${ }^{4}$ \\ Ю.М. Марусик ${ }^{1,2}$, К.Г. Михайлов ${ }^{3}$, Е.А. Кузьмин ${ }^{4}$
}

\footnotetext{
${ }^{1}$ Institute for Biological Problems of the North, FEB RAS, Portovaya Str. 18, Magadan 685000 Russia. E-mail: yurmar@mail.ru

2 Zoological Museum, University of Turku, FI-20014 Turku, Finland.

${ }^{3}$ Zoological Museum MGU, Bolshaya Nikitskaya Str. 2, Moscow 125009 Russia. E-mail: mikhailov2000@gmail.com

${ }^{4}$ Ulyanovsk State Pedagogical University, Stoletiya so dnya rozhdeniya Lenina Square 4, Ulyanovsk 432063 Russia. E-mail: kea87@bk.ru

${ }^{1}$ Институт биологических проблем Севера, ДВО РАН, Портовая 18, Магадан 685000 Россия.

3 Зоологический музей МГУ, ул. Большая Никитская, 2, Москва 125009 Россия.

4 Ульяновский государственный педагогический университет им. И.Н. Ульянова, Площадь столетия со дня рождения В.И. Ленина, 4, Ульяновск 432063 Россия.
}

KEY WORDS: Araneae, spider, shoshone, distribution, new synonym, Holarctic.

КЛЮЧЕВЫЕ СЛОВА: Araneae, паук, shoshone, распространение, новый синоним, Голарктика.

ABSTRACT. Tetragnatha qiuae Zhu, Song et Zhang, 2003, recorded previously from China and the Volga region, is synonymised with $T$. shoshone Levi, 1981, previously known from the Nearctic and Europe, east to Poland. Tetragnatha qiuae is reported for the first time from Mongolia.

PЕЗЮМЕ. Tetragnatha qiuae Zhu, Song et Zhang, 2003, ранее известная из Китая и Поволжья, сведен в синонимы к T. shoshone Levi, 1981, ранее известной из Неарктики и Европы, на восток до Польши. Tetragnatha qiuae впервые отмечена в Монголии.

\section{Introduction}

Tetragnatha qiuae Zhu, Song et Zhang, 2003 was described from Qinghai Province, Central China on the basis of both sexes. Recently, this species was reported from the European part of Russia [Sozontov, Esyunin, 2015]. Additionally, T. kovblyuki Marusik, 2010, described from the Aral Sea on the basis of the male, is a junior synonym of T. qiuae [Sozontov, Esyunin, 2015]. Comparison of the detailed figures provided by Sozontov and Esyunin [2015] with other species reported from Europe revealed that $T$. qiuae has identical copulatory organs and very similar chelicerae to those of $T$. shoshone Levi, 1981, a species known from across the Nearctic and several countries in Europe (Austria, Czech Republic, France, Germany, Hungary, Macedonia, Poland, Romania, Slovakia and Sweden [Helsdingen, 2015]). The goals of this paper are to synonymize the two names and outline the distribution of T. shoshone.

The material examined is kept at the Zoological Museum, Moscow Lomonosov State University, Moscow, Russia (ZMMU) and the Institute of Zoology, Chinese Academy of Sciences, Beijing (IZCAS).

\section{Taxonomy}

Tetragnatha shoshone Levi, 1981 $\left(\sigma^{\top}+\right)$

Tetragnatha shoshone Levi, 1981: 312, figs 158-166, pl. 7e-f

Tetragnatha shoshone: Uhl et al., 1992: 249, figs 1-39 ( $\sigma^{7}+$ ).

Tetragnatha qiuae Zhu, Song et Zhang, 2003: 176, figs 92AG, 93A-G ( $\sigma^{7}+$ ), syn. n.

Tetragnatha kovblyuki Marusik, 2010: 199, figs 1-6, 9-11 ( $\left.\sigma^{7}\right), 14$ [map].

Tetragnatha qiuae: Sozontov, Esyunin, 2015: 312, figs 1.1-3, 2.1-4, 3.1, 3.3, 4.1, 4.3-6 ( $\left.\sigma^{7}+\right)$.

For a complete synonym listing and references, see World Spider Catalog [2015].

MATERIAL EXAMINED. RUSSIA: 1 (ZMMU), Samara Area, environs of Syzran' Town, $53^{\circ} 08^{\prime} 49.3^{\prime \prime} \mathrm{N}, 48^{\circ} 25^{\prime} 31.5^{\prime \prime} \mathrm{E}$, in reeds, 30.05.2015 (E.A. Kuzmin). KAZAKHSTAN: $1 \sigma^{7}$ (ZMMU Ta-7409, holotype of T. kovblyuki), 1 O $^{7}$ (ZMMU Ta-7410, paratype of T. kovblyuki), Aral Sea, Barsakelmes Island, buguty [= artificial hollows for collecting water] near Barsakelmes Reserve Campus, 23.05.1982 (D.D. Piryulin); MONGOLIA: 1 フ , 1 (IZCAS), Khovd Aimag, nearby Khovd City, west shore of Har-Us nuur (lake), 47.96398 ${ }^{\circ} \mathrm{N}, 91.97303^{\circ} \mathrm{E}, 1160 \mathrm{~m}, 24.07 .2011$ (Meng Kaybier); $1 \sigma^{7}$ (IZCAS), Uvs Aimag, west shore of Uvs nuur (lake), $50.11372^{\circ} \mathrm{N}, 92.39433^{\circ} \mathrm{E}, 759 \mathrm{~m}$, reeds, 26.07.2011 (Uranbileg).

DESCRIPTION. Well described by Levi [1981], Uhl et al. [1992] and Sozontov, Esyunin, [2015].

COMMENTS. Comparison of the figures provided by Levi [1981], Uhl et al. [1992] and Zhu et al. [2003] reveals no differences between the two species in the shape of male palp and chelicera of both sexes, and therefore, the two names are synonymised.

The female specimen illustrated by Sozontov, Esyunin [2015] lacks a tooth on the cheliceral fang that is present in the holotype of $T$. qiuae and the paratype of $T$. shoshone as well as in females of the German population [see Uhl et al., 1992: figs 13-15]. 
NATURAL HISTORY. All publications and present data indicate that the species inhabits only reeds around large lakes.

DISTRIBUTION. This species has a Holarctic distribution and is known in the Nearctic from Quebec west to the Northwest Territory [Paquin et al., 2010], south to California [Levi, 1981]. In Europe, this species is known from eastern France [Bosmans, 2014] to the Volga River [Sozontov, Esyunin, 2015]. In Asia, it is recorded from northwestern Kazakhstan, Tuva [Sozontov, Esyunin, 2015], western Mongolia [present data] and Qinghai, China [Zhu et al., 2003].

ACKNOWLEDGEMENTS. We thank Shuqiang Li (Beijing, China) for providing access to unidentified material collected in Mongolia and Dr. Sergei L. Esyunin (Perm State University, Russia) for fruitful discussion. This project is supported by the Russian Foundation for Basic Research, grant No. 14-04-31178 (for E. Kuzmin). The proceedings of this paper are supported by Russian Science Foundation project No. 14-5000029 (for K. Mikhailov). English of the earlier draft was kindly checked by Sarah Crews (Californian Academy of Sciences, USA).

\section{References}

Bosmans R. 2014. Tetragnatha shoshone Levi, 1981 nouvelle espèce pour la France (Araneae, Tetragnathidae) // Revue Arachnologique. Série 2. No.1. P.11-12.

Helsdingen P.J., van. 2015. Fauna Europaea. Araneae. http:// www.european-arachnology.org/reports/fauna.shtml (accessed October 22nd, 2015)

Levi H.W. 1981. The American orb-weaver genera Dolichognatha and Tetragnatha north of Mexico (Araneae: Araneidae, Tetragnathinae) // Bulletin of the Museum of Comparative Zoology at Harvard College. Vol.149. No.5. P.271-318.

Marusik Yu.M. 2010. A new species of Tetragnatha Latreille, 1804 (Aranei: Tetragnathidae) from western Kazakhstan // Arthropoda Selecta. Vol.19. No.3. P.199-202.

Paquin P., Buckle D.J., Dupérré N., Dondale Ch.D. 2010. Checklist of the spiders (Araneae) of Canada and Alaska // Zootaxa. Vol.2461. P.1-170.

Sozontov A.N., Esyunin S.L. 2015. [Taxonomical remarks about two spider species from the genus Tetragnatha Latreille, 1804 (Aranei, Tetragnathidae)] // Zoologicheskiy Zhurnal. Vol.94. No.3. P.311-319 [in Russian, with English summary; English translation in: Entomological Review, 2015, vol.95, no.3, p.406-414].

Uhl G., Sacher P., Weiss I., Kraus O. 1992. Europäische Vorkommen von Tetragnatha shoshone (Arachnida, Araneae, Tetragnathidae) // Verhandlungen des Naturwissenschaftlichen Vereins in Hamburg. Bd.33. S.247-261.

World Spider Catalog (WSC). 2015. World Spider Catalog. Natural History Museum Bern, online at http://wsc.nmbe.ch, version 16, accessed on 22.10.2015

Zhu M.S., Song D.X., Zhang J.X. 2003. Arachnida: Araneae: Tetragnathidae // Fauna Sinica: Invertebrata. Vol.35. Beijing: Science Press. vii $+418 \mathrm{pp}$.

Responsible editor S. Koponen 